Int. J. of the Economics of Business, 2014

Vol. 21, No. 1, 3-6, http://dx.doi.org/10.1080/13571516.2013.864114

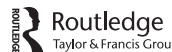

\title{
The Applied Economics of (International) Business: A Personal Perspective
}

\author{
PETER J. BUCKLEY
}

\begin{abstract}
The applied economics of international business (IB) has been successful in explaining foreign direct investment, the existence and growth of multinational enterprises (MNEs) and in integrating new concepts such as trust in the analysis of joint ventures. It now needs to face challenges in fully integrating culture into the rubric and into a comprehensive analysis of the varied phenomena of globalisation.
\end{abstract}

Key Words: International Business; Foreign Direct Investment; Multinational Enterprise; Globalisation; Applied Economics.

JEL classifications: L2, L14, F23, F6.

\section{International Business Research}

Research in international business (IB) is relatively recent, being conventionally dated to 1960 (Stephen Hymer's thesis, 1976) or John Dunning's (1958) American Investment in British Industry. Much of the early pioneering work was carried out by economists, notably Kindleberger (Hymer's supervisor) and Ray Vernon in addition to the long-running contribution of John Dunning (to 2009). IB has drawn on many other influences and is genuinely interdisciplinary - a fact highlighted by Dunning's theoretical apparatus, the eclectic paradigm. Influences from geography, history, sociology, political science, anthropology and management are all evident in the development of IB research, and this makes it an excellent focus for the study of the development of applied economics as it interacts with its near neighbours.

IB research is largely empirically (or problem) focused. It has tackled several "big issues" in its progress since 1958. Initially, the focus was on international flows of foreign direct investment, then on the existence, nature and power of multinational enterprises (MNEs), on the strategies of MNEs (notably their foreign-market entry and development strategies) and on the progress of globalisation. It has produced particularly insightful research in the area of joint ventures, drawing on a wide range of perspectives, and in the analysis of cultures, cultural difference and the role and meaning of "cultural distance" in business (Buckley, 2002). A strict criterion of "research success" of

Peter J. Buckley, Centre for International Business, Leeds University Business School, University of Leeds, Maurice Keyworth Building, Leeds LS2 9JT, United Kingdom; and University of International Business and Economics (UIBE), Beijing; e-mail: pjb@lubs.leeds.ac.uk.

(c) 2014 International Journal of the Economics of Business 


\section{P.J. Buckley}

an area of endeavour is the extent to which that area exports ideas to neighbouring areas - to economics more broadly defined, for instance. There have been periods and sub-areas where this has happened - the internalisation the-ory of the (multinational) firm (Buckley and Casson, 1976), aspects of interna-tionalisation theory including process theory (Johanson and Vahlne, 1977), the role of (national) culture in strategy formulation, borrowings from the analysis of joint ventures and (marginally) location theory aspects of the MNE have, at times, spilled over into disciplines. However, this has not been as frequent as could have been expected (Buckley and Lessard, 2005), and for long periods IB has been an importer of theory and methods from other disciplines.

\section{The Applied Economics of International Business}

Hymer (1960) made the crucial distinction between foreign direct investment (FDI), which implies control by the investor, and foreign portfolio investment, which is simply diversifying by adding foreign assets in a holding. This focused attention on the investor - the firm - and moved IB away from international trade theory, where goods move but factors do not, into the theory of the firm. Similarly, Dunning's (1958) research further highlighted the differentiated nature of capital flows and FDI's special status as international conduit of technology. Buckley and Casson (1976) made the multinational enterprise the organisational focus of innovation, internalised together with production and marketing to maximise returns from the initial "patent". The growth of markets as a result of technological (electronic commerce and communication) and political (liberalisation) changes has altered the Coasian balance towards outsourcing, and the emergence of new (national) locations has fostered offshoring, leading to newer forms of networked international companies. The rise of MNEs from emerging countries has led to debates as to whether "new MNEs" require new theories, but the flexible nature of internalisation theory has continued to provide satisfac-tory theoretical understanding. Globalisation is variously perceived as "partial", uneven and unequal and remains contested as to the most appropriate theoreti-cal lens of understanding (applied economics vs. political and social foci).

The future of IB remains interdisciplinary. Context is critical for IB, and there is dissent as to whether a single overarching framework is appropriate across these, largely national, contextual differences. The emergence of China in particular has led to calls for "Chinese management theories" in deliberate contradistinction to prevailing "Western" approaches. The challenge therefore is to show that applied economics can work in radically different contexts. The question should be put in terms of general and special theories. General theory is context free - "firms internalise markets up to the point where the costs of further internalisation outweigh the benefits". Special theories account for con-text - "internalisation pressures are strongest in the presence of tacit knowl-edge so we expect firms in knowledge intensive industries to pursue internalisation in core knowledge areas". Propositions about availability of cap-ital, imperfections in key markets in the source country and differing attitudes to risk aversion are all liable to suggest that special theories for certain nation-alities (or other groups) of firms are appropriate because the preconditions or assumptions of the operation of the theory will be thereby affected. 
Care must also be taken with categorizing when building theory across different national contexts. Anthropologists have shown that "native categories" differ across cultures. For instance, the meaning of "policeman" is not invariant to cultural understanding. It therefore behoves the applied IB economist to understand context, avoid category errors and to ground general theory in special circumstances. This is perhaps the most profound borrowing that applied economics can take from IB.

\section{Methods}

Because international business is comparative across nations, the comparative method is core to IB research. Three key comparators are operative in IB: across time (history), across space (geography) and against a carefully specified counterfactual. The MNE is an excellent experimental locus for applied economics because it holds organisation (the firm) constant and allows the analyst to vary place and time. The comparison of national units (subsidiaries) of the same firm allows insights into the impact of different national economies, organisations and cultures. Business histories of MNEs allow the focus to be on changes over time. Counterfactual methods are means of examining alternative states of the world in accordance with the thought experiment and have been used to assess the impact of FDI (as against a local firm alternative, exports from the source country or no investment at all). Applied economists perhaps regard this as uncontroversial given that all economic costs are opportunity costs in terms of the best alternative forgone.

IB researchers constantly seek new methods to understand the evolving new data produced by IB actors. These are not only quantitative, where economics has been a prime source, but also qualitative. Case-study research at the level of the firm and research on the decision making of individual managers is frequently combined with the quantitative analysis of secondary data in "mixed methods" IB. This mix is also fruitful for applied economists in general who are usually biased towards quantitative methods.

Several areas where both IB and applied economics may innovate are individual perceptions and expectations and (from Adam Smith) "sentiment" or morality. The integration of firm-level and managerial-level decision making is imperfect in both disciplines and is in need of integration. The role of nonpecuniary rewards - morality, sentiment, solidarity, cooperation - are not factored in to most modelling (exceptions are some analyses of joint ventures; Buckley and Casson, 1988), and this is overdue.

\section{The Nature and Form of New Research in International Business}

A big research issue - the future structure of the global economy - is central to IB research. The division of the global economy between large and small firms, stateowned and private, national and global is changing, and not unidirection-ally, across countries, industries and polities. The "balance of (economic) power" between the United States and China or Europe, Asia and North America or between the EU, NAFTA and ASEAN, the emergence of Trans-Pacific economic communities, the resource requirements of continued growth, the struggle against poverty, the impact on the climate of continued 


\section{P.J. Buckley}

industrialisation and urbanisation are all issues researchable under the banner of applied economics IB research. So too, in principle, are issues of cultural change, of managerial process and decision making and the (optimal) structure of organisations and institutions, including NGOs, international bodies, pressure groups and governmental organisations that are not traditionally the preserve of economists. The use of (in this case) internalisation theory to analyse the growth and decline of empires (Casson, Dark, and Gulamhussen, 2009) is an illustration that applied economics is capable of a wider remit than practitioners have heretofore allowed (Buckley and Casson, 1993). The context and interdisciplinary heritage of IB research can infuse applied economies with a new lease of life and improve its explanatory power. Similarly, IB research can continue to benefit from the continued importation of theory and method from applied economics, but this must be in the context of interdisciplinarity.

\section{References}

Buckley, P. J. 2002. Is the International Business Research Agenda Running Out of Steam? Journal of International Business Studies 33 (2): 365-373.

Buckley, P. J., and M. Casson. 1976. The Future of the Multinational Enterprise. London: Macmillan.

Buckley, P. J., and M. Casson, 1988. A Theory of Cooperation in International Business. In Cooperative Strategies in International Business, edited by F. J. Contractor and P. Lorange, 31-53. Lexington, MA: Lexington Books, D. C. Heath \& Co.

Buckley, P. J., and M. Casson. 1993. Economics as an Imperialist Social Science. Human Relations 46 (9): 1035-1052.

Buckley, P. J., and D. R. Lessard. 2005. Regaining the Edge for International Business Research. Journal of International Business Studies 36 (6): 595-599.

Casson, M. C., K. Dark, and M. A. Gulamhussen. 2009. Extending Internalization Theory: From the Multinational Enterprise to the Knowledge Based Empire. International Business Review 18 (3): 236-256.

Dunning, J. H. 1958. American Investment in British Manufacturing Industry. London: George Allen \& Unwin.

Hymer, S. 1976. The International Operations of National Firms: A Study of Direct Foreign Investment. Cambridge, MA: MIT Press. Original dissertation written in 1960.

Johanson, J., and J.-E. Vahlne. 1977. The Internationalisation Process of the Firm: A Model of Knowledge Development and Increasing Foreign Market Commitments. Journal of International Business Studies 8 (1): 23-32. 